\title{
Moral Analysis in the Videos of English Fairy Tales Channel and Its Relevance to Narrative Text Learning in Senior High School
}

\author{
Rizka Fitriani ${ }^{1}$, I Putu Ngurah Wage Myartawan ${ }^{2}$, I Nyoman Pasek Hadi \\ Saputra3
}

DOI: $10.35445 /$ alishlah.v13i3.887

Article Info

Keywords:

English Fairy Tales;

Moral;

Narrative text;

Learning

Kata kunci:

English Fairy Tales;

Moral;

Teks Naratif;

Pembelajaran

\begin{abstract}
This study analyzes the moral values of legends and fairy tales on the English Fairy Tales YouTube channel and examines its relevance to narrative text learning in schools. The approach used is qualitative research, with descriptive type. The sample videos taken from the English Fairy Tales channel are five videos. According to theory, analysis of moral values is carried out by looking at video samples and describing them. In contrast, relevance analysis will be carried out by reviewing the applicable learning syllabus. The research found that the videos analyzed contain values always to be grateful to God, care for others, be diligent, be brave, help each other, keep promises, and never give up. In addition, the moral values found in legends and fairy tales on the English Fairy Tales YouTube channel have relevance to the teaching of narrative texts in class X of Senior High School because the moral values contained in legends and fairy tales on the English Fairy Tales YouTube channel can support the use of English Fairy Tales channel videos as learning media that is in line with the learning competence.
\end{abstract}

\begin{abstract}
Abstrak
Penelitian ini bertujuan untuk menganalisis nilai moral pada legenda dan dongeng di kanal Youtube English Fairy Tales, serta menganalis relevansi dari nilai moral yang ditemukan dengan pembelajaran narrative teks di Sekolah Menengah Atas. Pendekatan yang digunakan adalah penelitian kualitatif, dengan jenis deskriptif. Sampel video yang diambil dari kanal English Fairy Tales berjumlah 5 video. Analisis nilai moral akan dilakukan dengan cara mencermati sampel video dan menjabarkannya menurut teori, sedangkan analisis relevansi dilakukan dengan cara meninjau silabus pembelajaran yang berlaku. Dari penelitian yang dilakukan, didapatkan hasil bahwa video-video yang dianalisis mengandung nilai untuk selalu besyukur kepada Tuhan, peduli terhadap sesama, rajin, berani, tolong-menolong, menepati janji, dan pantang menyerah. Nilai-nilai moral yang ditemukan pada legenda dan dongeng di kanal Youtube English Fairy Tales memiliki relevansi dengan pembelajaran narrative teks di kelas X Sekolah Menengah Atas, karena nilai moral yang terkandung pada legenda dan dongeng tersebut dapat mendukung penggunaan video kanal English Fairy Tales sebagai media pembelajaran yang sejalan dengan kompetensi pembelajaran.
\end{abstract}

\footnotetext{
${ }^{1}$ Universitas Pendidikan Ganesha, Singaraja, Indonesia Email: rizkafitriani23@undiksha.ac.id

${ }_{2}^{2}$ Universitas Pendidikan Ganesha, Singaraja, Indonesia Email: wmyartawan@undiksha.ac.id

3 Universitas Pendidikan Ganesha, Singaraja, Indonesia

Email: hadi.saputra@undiksha.ac.id
} 


\section{INTRODUCTION}

Technological developments affect humans' social and economic fields and the field of education that has become an essential part of the learning process in and out of the class. Implementation of digital technology in education is an urgent thing and a good strategy in this era. Technology has influenced almost all of society's aspects, and it dramatically changes society's segments (Ahmadi, 2018). Quoted from Technology and Communication Board Website (2020), technology in education can provide convenience and benefits for teachers and students. Among them are (1) easy access, (2) affordable cost: (3) more flexible study time, and (4) opportunity to gain broader insight. Of course, these conveniences are supported by the many platforms that support technology-based learning, such as Brainly, Edmodo, Schoology, Google Classroom, WhatsApp, and YouTube.

According to the several platforms mentioned above, YouTube is the most famous platform and has many users. YouTube is a free web-based service that allows users to upload, view, rate, share, add to playlists, report, comment on videos, and subscribe to other users (Srinivasacharlu, 2020). People's needs for video content that support their daily activities can be found on YouTube. YouTube can be used as learning support because there is a lot of content on YouTube with educational value. For example, the range of learning Mathematics, the content of chemistry formulas, and any kinds of language content in the form of stories. From the educational content on YouTube, the author is more interested in fairy tale content. One example of a YouTube channel that contains fairy tale content is the English Fairy Tales channel. English Fairy Tales is a YouTube channel that broadcasts fairy tales that are popular in the world. This channel was founded on June 6, 2016. As of July 12, 2021, English Fairy Tales already has a following of 2.14 million accounts, with a video view duration of approximately 597.5 million times. This channel has the English language of instruction and many versions of the channel from various countries, such as Arabic, German, Greek, Indonesian.

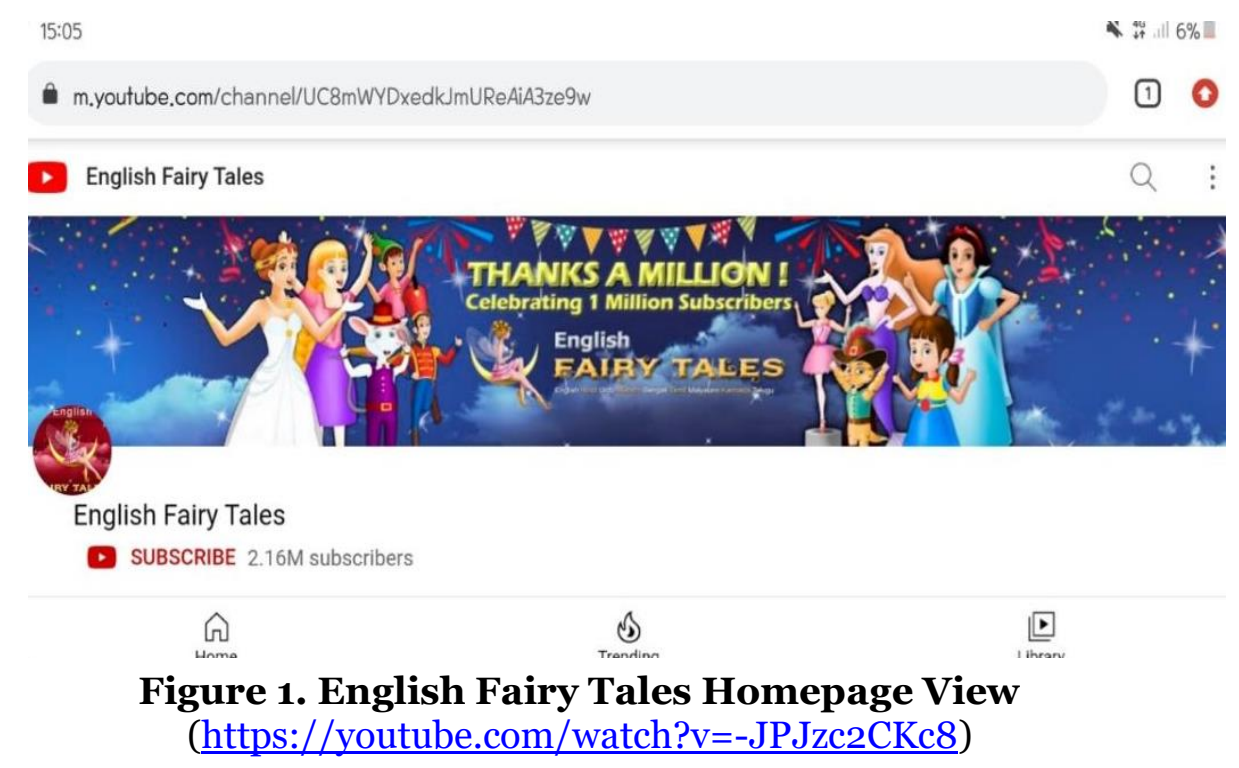

If it is related to education, the existence of the English Fairy Tales channel will be beneficial as a media to support learning, which serves to convey material to students. One of the learning materials that English Fairy Tales will help with is narrative text material. Sulistyo (2013) defines a narrative as a story. Most narratives are imaginary stories, but sometimes narratives can be factual too. The narrative includes fairy tales, fables, mystery, stories, science fiction, romance, horror, etc. Furthermore, Langan (in Lubis, 2014) states that narrative text is a legendary story that aims to 
entertain the reader. From the two previous definitions, it can be concluded that narrative text is a fictional text that seeks to engage the reader and provide moral values.

Morals in literary works usually reflect truth values from the author's view and what the author wants to deliver to readers (Susana, 2018). According to Barcalow (1994), moral value is an ethical norm that may be evaluated as good or bad, right or wrong, acceptable or unacceptable, prohibited or permitted regarding the actions, attitudes, obligations, morals, manners, etc. In other words, moral values are beliefs and values of people that conform to the usual standards of what is right and what is wrong. Thus, moral values in narrative texts could be a good measurement for readers to determine the positive and negative sides of things that happened in real life and become a standard to think about the consequences before deciding something and acting.

On the other hand, the narrative text becomes genres studied in high school, especially in the tenth grade. The existence of narrative texts in students' learning is in line with the 2013 Curriculum base, which aims to develop students' morals. Every narrative story has moral values that could be a good example to enhance students' morality. Santoso et al. (2021) state that the learning competence in the 2013 Curriculum aims to develop student character.

This research describes the moral values in the English Fairy Tales channel videos and their relevance to narrative text learning in Senior High School. Using the English Fairy Tales channel videos in the narrative text course could motivate students to read texts in a foreign language by making reading enjoyable. The videos provided in the channel are entertaining, attractive, well delivered, and appeal to the imagination of virtually all readers. Thus, the researcher conducts the present study. Then, the theory of moral values used is the theory of Keraf. Keraf (in Laksono, 2015) classifies values into several kinds, such as individual value, social value, and religious value. Individual value includes self-sacrifice, courage, honesty, fairness, hard work, and caution in behaviour. Social value includes cooperation, helpfulness, harmony, peace, giving advice, and caring for others. Meanwhile, religious value includes believing in God, surrendering to God (putting his trust), and asking for forgiveness. The purpose of this research is to examine the moral values in the English Fairy Tales channel video, its relevance to narrative text learning in high school, and to enrich the scientific treasures of moral education and English language learning.

Similar research that has been done is the research of Santoso et al. (2021) entitled Moral Analysis in The Videos of Dongeng Kita Channel and Its Relevance to Indonesian Learning, and Hariandi's et al. (2020) research entitled Moral Analysis in the Animated Films of Nusa Rara and Upin Ipin as Educational Shows. Santoso's et al. research aims to analyze the moral values of the Dongeng Kita channel videos and find their relevance in learning Indonesian. In contrast, Hariandi's et al. research examines the moral values of the animated films Nusa Rara and Upin Ipin as educational shows. If compared, it is found that the two previous studies and the research to be conducted both analyze the moral values in the video. However, there are differences in terms of the video sources used. The previous studies used Dongeng Kita Channel and TV Channel as subjects, while the present study uses the English Fairy Tales channel. Then, the previous studies analyzed narrative text, specifically folklore and animated films. Meanwhile, this study analyses narrative text in general. In addition, the research that was conducted also analyze the relevance to narrative text learning in the X class of Senior High School, which was not done in the two previous studies.

\section{METHOD}

This research was designed in a qualitative descriptive form. Mantra (in Siyoto \& Sodik, 2015) defines qualitative methods as research procedures that produce data in words or words from the people observed. Meanwhile, according to Kuntjojo (2009), descriptive research is research conducted to describe the variables studied.This research was designed in a qualitative 
descriptive. A qualitative descriptive design was used in this research because the analysis focused on descriptive analysis in the form of moral values in the English Fairy Tales channel videos and its relevance to narrative text learning in Senior High School at X grade.

The data source in this study is English Fairy Tales channel videos, with data in the form of five randomly selected fairy tale videos. The titles of the videos chosen are The Cheerful Granny Story, Mother Hole in English, The Golden Headed Fish, The Lady and The Lion, and The Legend Of The Waves. The videos were chosen because they are considered capable provide various moral values so that the analysis results are more diverse. The data collection method used is observation and documentation. The researcher conducts observation digitally, in which the subject that will be observed is in the form of digital data, which is English Fairy Tales channel videos. Digital observations were made to see the state of the English Fairy Tales channel, along with its videos. Meanwhile, documentation was carried out to determine the relevance of the English Fairy Tales video channel with narrative text material in English learning for Senior High School, X class, contained in the syllabus.

The data analysis technique used in this study is the Miles and Huberman model. The elements contained in this model include (1) data reduction, (2) data presentation, and (3) verification (Sugiyono, 2017). Data reduction is carried out by sorting out important data obtained from data collection. If there is data that is not needed, it will be deleted. The presentation of the data is done by presenting the research results. In this study, the presentation of data is done by presenting and discussing the moral values found and their relevance to narrative text learning. Verification is concluding. In this research, verification is done by concluding the data presentation that has been done.

\section{FINDINGS AND DISCUSSION}

\section{Moral Values in English Fairy Tales Channel Videos}

Based on the analysis that has been conducted on five videos on the English Fairy Tales channel, there are eight moral values which are identified, namely grateful (religious morals), caring for others (social morals), humble (individual morals), diligent (individual morals), brave (individual morals), help the others (social morals), keep promises (personal morals), and never give up (individual morals). The following is an analysis of moral values.

\section{Table 1. Moral Values Found}

\begin{tabular}{|c|c|c|c|}
\hline No. & Title & Moral Values & Story Snippet \\
\hline 1 & $\begin{array}{l}\text { The } \\
\text { Cheerful } \\
\text { Granny } \\
\text { Story }\end{array}$ & $\begin{array}{l}\text { Always grateful for } \\
\text { God's gift (religious } \\
\text { moral) and always care } \\
\text { for others (social } \\
\text { morals) }\end{array}$ & $\begin{array}{l}\text { An older woman found a jug in the forest while looking for } \\
\text { firewood, and it was filled with gold. She brought it home and } \\
\text { intended to share the gold with his neighbours. Halfway, the } \\
\text { gold in the jar turned to silver, charcoal, and a big stone until } \\
\text { the jug's house turned into a cotton beast. Despite experiencing } \\
\text { many changes, she is always grateful and does not complain } \\
\text { about what she has got. Suddenly, everything that had changed } \\
\text { in the jug was found in her house. Then she distributed the gold } \\
\text { she got to her neighbours. }\end{array}$ \\
\hline 2. & $\begin{array}{l}\text { Mother } \\
\text { Hole in } \\
\text { English }\end{array}$ & $\begin{array}{l}\text { Diligent (individual } \\
\text { morals) }\end{array}$ & $\begin{array}{l}\text { Stella is a diligent and hardworking girl, while her sister, Bella, } \\
\text { is a lazy girl. One day Stella accidentally dropped the spindle } \\
\text { into the well. She jumped in and took the spindle into the well, } \\
\text { then she found herself in another lovely place. Stella met } \\
\text { Mother Hole and helped Mother Hole that Mother Hole gifted } \\
\text { her a beautiful dress made of gold. Bella also wanted to follow } \\
\text { what Stella did, but Mother Hole did not reward her because } \\
\text { she was very lazy. She gave her a punishment instead for what } \\
\text { she had done. }\end{array}$ \\
\hline 3 . & $\begin{array}{l}\text { The } \\
\text { Golden } \\
\text { Headed } \\
\text { Fish }\end{array}$ & $\begin{array}{l}\text { Courageous } \\
\text { (individual morals) } \\
\text { Please help (Social } \\
\text { Morals) }\end{array}$ & $\begin{array}{l}\text { A prince in Egypt is looking for The Golden-headed fish for his } \\
\text { father's recovery. He must find the fish within } 100 \text { days. After } \\
\text { seeing the fish, he decided to let it go because he felt sorry to } \\
\text { kill it. As a result of his actions, he went to prison to get }\end{array}$ \\
\hline
\end{tabular}


punishment. The mother releases him from prison. He found a brave and very loyal guard by his side until he married a princess. Then the prince returned to his father's kingdom, and it turned out the bodyguard was the incarnation of the goldenheaded fish he had saved.

\begin{tabular}{lll}
\hline 4. & $\begin{array}{l}\text { The Lady } \\
\text { and The } \\
\text { Lion }\end{array}$ & $\begin{array}{l}\text { Keeping Promises } \\
\text { (Individual Morals) }\end{array}$
\end{tabular}

The Marchant met a lion while looking for a bird for his beloved daughter, Amelia. The bird brought by Marchant belonged to a lion which turned out to be a prince. The Marchant promised to give him whatever he first saw when he got home in exchange for the bird. Then, Amelia was the first person she saw when she got to her house. Following the promise he had made, the merchant finally gave Amelia to the lion and married.

\begin{tabular}{lll}
\hline 5. & $\begin{array}{l}\text { The } \\
\text { Legend Of } \\
\text { The Waves }\end{array}$ & $\begin{array}{l}\text { Never Give Up } \\
\text { (Individual Morals) }\end{array}$
\end{tabular}

Zaenko is a poor young man who likes to sing while playing the guitar on the beach. He doesn't have much money to marry any women. One day, his singing is heard by the King of the sea and is enjoyed by the inhabitants of the sea. The sea king gave him a present, and he became rich. However, he still couldn't find the right woman to marry. Then, Zaenko dives to the sea palace and fills his promise to sing for the sea King, every time Zaenko plays music. The sea king always dances to shake the sea. As a reward, the sea King asks Zaenko to marry one of his daughters. Then, finally, after all his efforts to find his true love and money in his whole life, he marries the youngest daughter of the sea King and becomes the prince of the sea.

\section{Moral Values of Being Grateful}

When talking about gratitude, people will more often find that appreciation refers to time and consistent character. However, that does not mean that gratitude cannot develop; instead, gratitude influences determining a person's character (Emmons \& McCullough, 2004). As conveyed in the story entitled The Cheerful Granny Story, this older woman is grateful every day. Finally, she becomes a person who has a kind character and also likes to share.

It is also stated by Wood, Froh, \& Geraghty (2010), that gratitude and social integration sequentially enhance each other. When someone owns gratitude, the social value that is in him will develop. As told in this video, an older woman was happy to get gold; when the gold turned silver, she did not complain and remained grateful. Even though the silver eventually turned into a cotton beast, he did not feel disappointed and still accepted whatever was given by God. Because of the gratitude he had, God gave him more than he imagined. Finally, he was able to distribute gold to his neighbours as a form of gratitude to God. The moral message that everyone grateful can take from this story is that when someone is grateful for God's gift, God will give more than what we ask for, and do not forget to share with others.

\section{Moral Values of Care to Each Other}

The reality of tolerance and social care showed by students is marked by respecting the opinions of others, being friendly without distinguishing ethnicity and religion, mutual respect, controlling emotions, not mocking friends, designing and carrying out various social activities, respecting school officials, helping each other, visit sick friends, and mourn when a student's parent dies (Sari, 2014). As exemplified in the video entitled The Cheerful Granny Story, where an older woman who gets gold shares it with her neighbours as a form of caring for others. The older woman feels what other people feel so that care arises in her. Social care in children can be interpreted as an attitude of understanding the conditions of others according to the views of others, not according to their opinions (Tabi'in, 2017). 


\section{Moral Values of Being Diligent}

A diligent attitude must be cultivated from an early age because many things people will get when they become diligent people. According to Sari (2019), there are several benefits that we get if we have a diligent attitude, including being able to grow patience in ourselves, the work being done will feel fun, a diligent attitude can certainly make a work optimally, of course, when a work is maximal, people will trust us to do our best. In addition, a diligent attitude can lead to motivation to develop, and a diligent attitude will create a sense of conscientiousness and improve skills. In the story Mother Hole in English, we can imitate the diligent attitude shown by Stella. Stella, who is used to doing housework, makes her a patient girl even though her mother is mistreated every day. In addition, because of his diligent attitude, he won the trust of Mother Hole to do the work he ordered so that he received a gift in the form of a dress made of gold. This story hopes that the children will emulate Stella's diligent attitude, diligently helping with homework and diligently studying.

\section{Moral Values to Be Brave}

Courage is an attitude against the fear that is in us. Dare to be one of the character education that must be instilled in every individual. Certainly be brave in terms of goodness, not in terms of evil, such as daring to fight parents or teachers when reprimanding us when we make mistakes. According to Ma'rufi et al. (2018), Courage is an attitude to do something without worrying too much about bad possibilities. Courage can also be interpreted as the nature of defending and fighting for the truth by facing all possible risks. As exemplified by the Prince in Egypt in the story The Golden Headed Fish, who dared to release the fish he had been looking for 100 days for his father's treatment. He felt sorry for the fish because he knew that the fish would be killed, even though he must be punished for what he had done. In the end, the Prince's father managed to recover without killing the fish, and the Prince was rewarded with kindness for releasing the fish. When we dare to uphold the truth, then goodness will continue to exist within us.

\section{Moral Values of Help the Others}

The young generation must have a character that reflects the nation's personality, namely an attitude of caring, helping, and having a human spirit (Prahesty \& Suwanda, 2016). People are social beings who need each other. One of the social forms of human behaviour is to help. Please help those in society shape the nation's mentality to become more characterized and give birth to many noble values beneficial for life (Putra et al., 2018). In the video, The Golden Headed Fish is taught to help anyone. It is told that the Prince helps a fish killed for his father's treatment, and it turns out that this fish can transform into a human and become the Prince's loyal guard. Time passed, the Prince's father could recover without having to kill the fish. Finally, the Prince returned to the palace and lived happily. The moral message that we can take from the story is that please help in goodness will bring goodness to us.

\section{Moral Values of Keeping Promises}

The attitude of keeping promises is an attitude obtained by trusted people. When someone has the right attitude, that person is someone who can be charged. This is because the right attitude to promise has a relationship with a trustworthy attitude (Heraningrum et al., 2015). In the story of The Lady and The Lion, everyone can imitate the King in an attitude of keeping his promise. He got it because the Lion King believed in him. The King promised the lion because he had taken the lion's singing bird. The King kept his promise to give up whatever he first saw when he returned home and in giving up his daughter to marry a lion who unexpectedly he was a human. From this 
story, everyone can take a lesson always to be a person who keeps promises to gain the trust of others.

\section{Moral Values of Never Give Up}

Never giving up is an attitude related to hard work and strong motivation to achieve success. According to Mayasari (2014), unyielding is a mental attitude to bounce back from difficult situations. In the legend, the waves, the uncompromising attitude is exemplified by Zaenko, who never gives up on his life. He struggled to eat when he had nothing until he finally met the King of the sea, who gave him a diamond. Zaenko used the gift to open a business to become a rich man. Young people can emulate Zaenko's unyielding attitude not to give up easily achieving what they dream of.

\section{Relevance to Narrative Text Learning in Senior High School}

The narrative text is one of the learning materials at the Senior High School level in X class and is taken during semester 1. One of the essential competencies in this learning is to capture the meaning of oral and written narrative texts in simple legends. Some aspects of indicators in this learning are as follows.

a. Cognitive Aspect. The cognitive aspect is a domain that includes mental activities such as thinking, understanding, memorizing, applying, analyzing, synthesizing, and developing skills (Nurbudiyani, 2013). In this case, students are expected to be able to analyze the meaning contained in the legend.

b. Affective aspect. According to Krathwohl (in Nurbudiyani, 2013), the affective element is related to attitudes and values. In this case, students can pay more attention to learning, be. They were disciplined in following the learning process, being motivated to learn, and so on.

c. Psychomotor aspects. Psychomotor aspects are skills or acting after a person receives a particular learning experience (Nurbudiyani, 2013). In this case, students can imitate the values or moral messages contained in the legend.

Based on the indicators and aspects above, the design of narrative learning in the form of a legend uses learning media in the English Fairy Tales channel. This learning design has been adapted to the application of distance learning in the COVID-19 pandemic situation. The application used as a class is WhatsApp Group, with a time allocation of 2x40 minutes. An example of the video used is The Legend of The Waves.

YouTube is one of the alternative learning media during the COVID-19 pandemic. This is because YouTube contains various learning resources if someone good at sorting them out. One of the YouTube channels that can be used as a source of student learning is the English Fairy Tales channel. The channel contains many folk tales and legends that can be studied for their meaning. Of course, the video is very relevant for learning narrative text. Folk tales and legends in the form of digital videos on the English Fairy Tales channel could attract students' curiosity, increase their interest, create wonder, and elicit a powerful emotional response and personal involvement. Using digital forms of texts could make it easier for students to understand the stories and motivate them to know the meaning of the content. The exciting features of the English Fairy Tales channel videos, such as animation, dubbing, and subtitles, could attract students attention in learning narrative text. The features also help students increase their reading and listening comprehension. Besides, video learning can motivate students to be more enthusiastic (Santoso et al., 2021). So, this learning is a form of innovation from online learning, which only sends assignments without discussion. Students can learn while analyzing the meanings contained in stories or legends by 
reading and listening. This is also following the essential competencies that students must take in narrative text learning.

Table 2. Lesson Plan using English Fairy Tales Videos LESSON PLAN

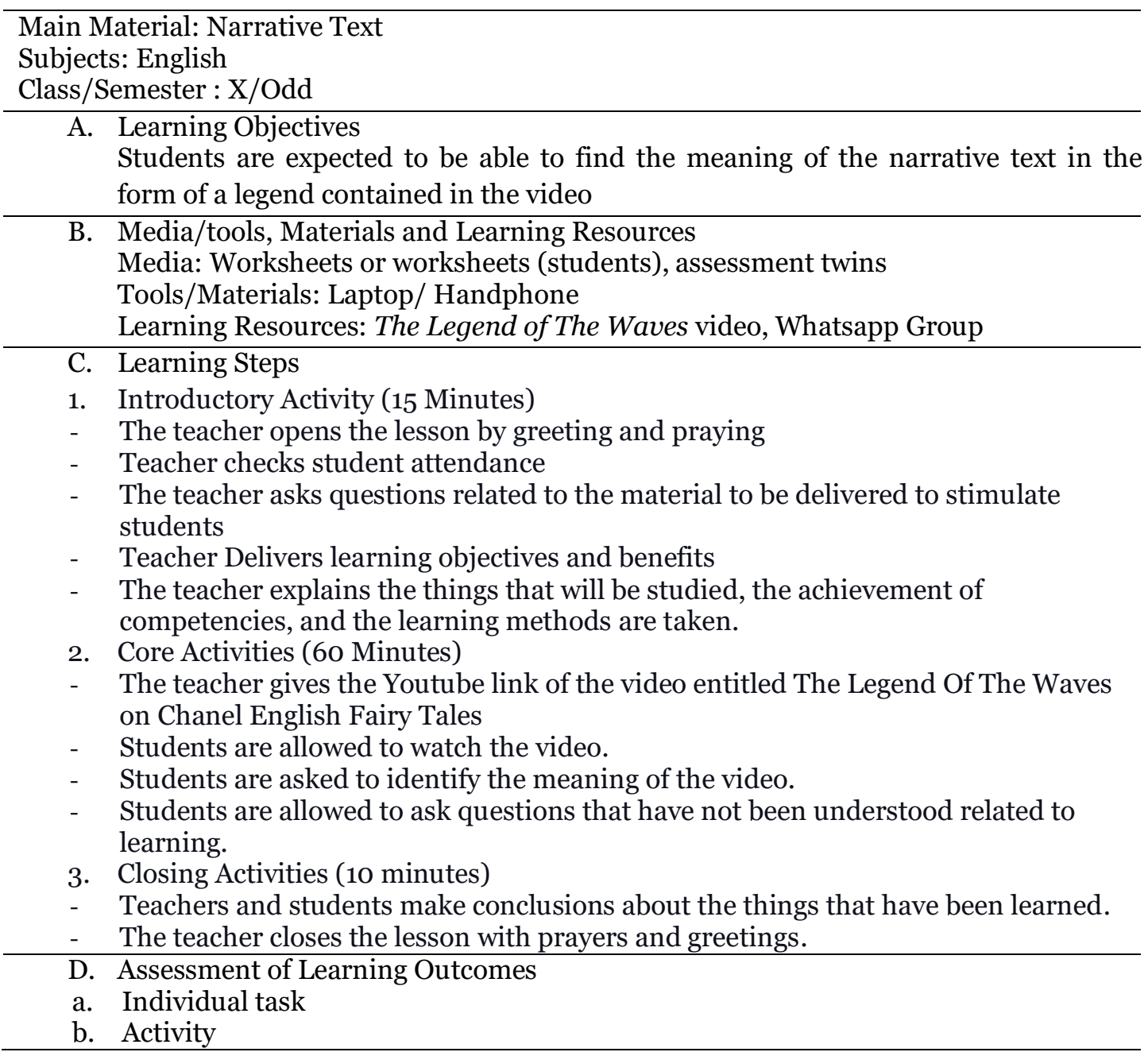

The important one is that students could take moral values contained in each story as their character development. The moral values of the stories could help students to decide and act more carefully in their lives. Characters in narrative texts are either good or bad. The sharp division between good and bad characters help students to take the values that good people will always be rewarded, while bad people will always be punished. It could awaken their desire to behave in the same positive way. Therefore, narrative texts could contribute significantly to the students' social education as well. The moral values contained in some of the stories from the English Fairy Tales channel are as follows, (1) the attitude of always being grateful to God for all His gifts so that an attitude is formed not to complain easily; (2) caring for each other to form a generation that is not selfish; (3) diligent in learning to be able to create an intelligent generation; (4) the attitude of having the courage to make decisions with all responsibilities to form a generation that is not afraid to make the right decisions; (5) the attitude of helping each other in terms of goodness to create a generation that upholds the value of togetherness; (6) always keep the promise to form a disciplined and trustworthy generation; and (7), unyielding attitude to develop a generation that is not easily discouraged. From all those moral values, it can be concluded that each story has a moral value that can be taken and used as guidelines to think and act in real life. The English Fairy Tales channel helps teachers and students digitally access many narrative stories and learn many things 
through them, such as reading, listening, and getting moral values in exciting ways. Thus, the English Fairy Tales channel could be an effective alternative for teaching narrative text for tenthgrade students during school from home.

\section{CONCLUSION}

Based on the analysis above, it can be concluded that the stories contained in the English Fairy Tales channel provide an excellent moral message for the audience. The moral values contained in some of the stories from the English Fairy Tales channel are as follows, (1) the attitude of always being grateful to God for all His gifts so that an attitude is formed not to complain easily; (2) caring for each other to form a generation that is not selfish; (3) diligent in learning to be able to create an intelligent generation; (4) the attitude of having the courage to make decisions with all responsibilities to form a generation that is not afraid to make the right decisions; (5) the attitude of helping each other in terms of goodness to create a generation that upholds the value of togetherness; (6) always keep the promise to form a disciplined and trustworthy generation; and (7), unyielding attitude to develop a generation that is not easily discouraged. English Fairy Tales channel is one of the channels on YouTube that can be used as a learning medium. In addition, the video also has relevance to narrative text learning at the Senior High School level in X class. English Fairy Tales channel is one of the channels on YouTube that can be used as a learning resource. Digital videos on the English Fairy Tales channel could attract students' curiosity, increase their interest, create wonder, and elicit a robust emotional response and personal involvement of students. Using digital forms of texts could make it easier for students to understand the stories and motivate them to know the meaning of the content. The exciting features of the English Fairy Tales channel videos, such as animation, dubbing, and subtitles, could attract students attention in learning narrative text. The features also help students increase their reading and listening comprehension. English teachers in schools are expected to take advantage of the English Fairy Tales channel as a learning resource.

\section{REFERENCES}

Ahmadi, M. R. (2018). The Use of Technology in English Language Learning: A Literature Review. International Journal Research in English Education. https://www.researchgate.net/publication/326014484 The Use of Technology in Engl ish Language Learning A Literature Review

Barcalow, Emmet. (1994). Moral Philosophy. California: Wadsworth Publishing Company. Bertens, $\mathrm{K}$.

Emmons, R. A., \& McCullough, M. E. (2004). The Psychology of Gratitude. New York: Oxford University Press.

English Fairy Tales. Retrieved on July 18, 2021 from https://youtube.com/watch?v=-JPJzc2CKc8

Hamdan. (2018). Industri 4.0: Pengaruh revolusi industri pada kewirausahaan demi kemandirian ekonomi. Jurnal Nusamba, 3(2), 1-8.

Hariandi, A. et al. (2020). Moral Analysis in the Animated Films of Nusa Rara and Upin Ipin as Educational Shows. Al Islah: Jurnal Pendidikan, 12(2). https://doi.org/10.35445/alishlah.v12i2.220

Herianingrum, S., Hapsari, M. I., \& Syahruddin. (2015). Implementasi nilai-nilai amanah pada karyawan hotel Darussalam Pondok Pesantren Gontor di Ponorogo. Jurnal Al Tijarah. http://repository.unair.ac.id/57250/1/Karya\%20Ilmiah\%2007 Sri\%20Herianingrum.pdf

Hermawan, H. D. (2018). Implementation of ICT in Education in Indonesia During 2004-2017. International Symposium on Educational Technology (ISET) Paper. Retrieved from https://ieeexplore.ieee.org/document/8456200/authors\#authors

Kuntjojo. (2009). Metodologi Penelitian [Research Metodology]. Kediri:

Laksono, R. E. B. (2015). Moral Sosial dan Moral Religi dalam Sinetron Televisi. Unpublished thesis. Yogyakarta: UIN Sunan Kalijaga. 
Lubis, B. F. (2014). Writing Narrative Text. English Education Journal, 2(1). https://doi.org/10.24952/ee.v2i1.115

Ma'rufi, A., Suryana, Y., \& Muslihin, H. Y. (2018). Hubungan sikap berani dengan kepercayaan diri pada kegiatan senam irama. Jurnal ilmiah pendidikan guru sekolah dasar. https://ejournal.upi.edu/index.php/pedadidaktika/article/download/13296/8511

Mayasari, R. (2014). Mengembangkan pribadi yang tangguh melalui pengembangan keterampilan resilience. Jurnal Dakwah. https://media.neliti.com/media/publications/76088-IDmengembangkan-pribadi-yang-tangguh-melal.pdf

Nurbudiyani, I. (2013). Pelaksanaan pengukuran ranah kognitif, afektif, dan psikomotorik pada mata pelajaran Ips kelas III SD Muhammadiyah Palangkaraya. Anterior Journal. http://journal.umpalangkaraya.ac.id/index.php/anterior/article/view/295/288

Prahesty, R. E., \& Suwanda, I. M. (2016). Peran Ekstrakulikuler Palang Merah Remaja Dalam Membentuk Sikap Tolong Menolong Siswa di SMP 5 Sidoarjo. Kajian Moral dan Kewarganegaraan. https://adoc.pub/peran-ekstrakurikuler-palang-merah-remaja-dalammembentuk-si.html

Putra, E. (2018). Eksistensi kebudayaan tolong menolong (Kaseise) sebagai bentuk solidaritas sosial pada masyarakat Muna Neo Societal Journal. js.uho.ac.id/index.php/NeoSocietal/article/view/4045

Santoso, S, \& Negara, I. H. P. (2021). Penanaman Minat Bertani Pada Siswa TK Melalui Aplikasi Edutani. Jurnal Sistema, 2(1). https://doi.org/10.2493/sjp.v21i.733

Santoso, S. et al. (2021). Moral Analysis in The Videos of Dongeng Kita Channel and Its Relevance to Indonesian Learning. Al Ishlah: Jurnal Pendidikan, 13(1). https://doi.org/10.35445/alishlah.v13i1.441

Saraswati, E. (2018). Peran Youtube dalam Menunjang Pembelajaran Bahasa dan Sastra Indonesia di SMA. Working Paper. Badan Pengembangan dan Pembinaan Bahasa. Retrieved from repositori.kmdikbud.go.id/10447/dokumena makalah 1540352619.pdf

Sari, S. R. (2019). 6 Manfaat Tak Terduga Jika Kamu Memiliki Sikap Tekun. Retrieved from https://www.idntimes.com/life/inspiration/shella-rafika-sari/6-manfaat-yang-akan-kamudapatkan-saat-memiliki-sikap-tekun-c1c2

Sari, Y. M. (2014). Pembinaan Toleransi dan Peduli Sosial dalam Upaya Memantapkan Watak Kewarganegaraan (Civic Disposition) Siswa. Jurnal Pendidikan Ilmu Sosial. https://ejournal.upi.edu/index.php/jpis/article/view/2059

Srinivasacharlu, A. (2020). Using Youtube in Collegesn of Education. Shanlax International Journal of Education. https://eric.ed.gov/?id=EJ1256049

Sulistyo, I. (2013). An Anlysis of Generic Structure of Narrative Text Written by The Year Students of SMA Yasha Gubug. Eternal English Teaching Journal. http://103.98.176.9/index.php/eternal/article/view/1956/1572

Siyoto, S. \& Sodik, M. A. (2015). Dasar Metodologi Penelitian. Yogyakarta: Literasi Media Publishing.

Sugiyono. (2017). Metode Penelitian Kualitatif. Bandung: Alfabeta.

Susana, E. (2018). Moral Value in Charlotte Bronte's Novel. The Creative Commons Attribution License. KnE Social Sciences.

Tabi'in, A. (2017). Menumbuhkan Sikap Peduli Pada Anak Melalui Interaksi Kegiatan Sosial. Journal of Social Sciene Teaching. https://journal.iainkudus.ac.id/index.php/Ijtimaia/article/view/3100

Wahyudi, H. S., \& Sukmasari, M. P. (2014). Teknologi dan Kehidupan Masyarakat . Jurnal Analisa Sosiologi, 2(1), 13-24. https://doi.org/10.20961/jas.v3i1.17444

Web Dewan Teknologi Informasi dan Komunikasi. (2020). Empat Kelebihan dan Kekurangan dalam Menerapkan E-Learning. Retrieved on July 18, 2021 from www.wantiknas.go.id./id/berita/empat-kelebihan-dan-kekurangan-dalam-menerapkanelearning

Wood, A. M., Froh, J. J., \& Geraghty, A. W. (2010). Gratitude and Well-Being: a review and theoretical integration. National Library of Medicine. https://www.sciencedirect.com/science/article/abs/pii/So272735810000450?via\%3Dihub 